\title{
Sandwich Training in Higher Education as one Major Strategic Axis at the Heart of the Attractiveness of a Territory: Some Lessons Learned from the Pioneering Example of the University Institute of Technology Corsica
}

\author{
Christophe Storaï ${ }^{1}$ and Laetitia Rinieri ${ }^{2}$ \\ ${ }^{1}$ University Institute of Technology Corsica, University of Corsica, Corte, France \\ ${ }^{2}$ University-sponsored Placements \& Apprenticeships Service, \\ Campus Grimaldi, Corte, France
}

Correspondence should be addressed to: Christophe Storaï; storai@univ-corse.fr

Received date: 8 September 2013; Accepted date: 6 January 2014; Published date: 2 July 2014

Copyright (C 2014. Christophe Storaï and Laetitia Rinieri. Distributed under Creative Commons CC-BY 3.0

\begin{abstract}
In today's fast-globalizing world, the much-hyped concept of place branding has become critical for regions in fierce global competition to capture and secure geographically-mobile investment. In this environment, the effort to attract and promote inward investment is a challenge requiring coordination across several fronts, where socio-economic fabric along with skilled qualified human resources emerges high on the list of critical variables. Corsica is an island economy marked by the complete absence of any of the big holdings and multinationals that fuel and forge the worldwide economy. Equally absent are any of the kind of medium-sized enterprises servicing big business that have spearheaded local economies in other regions like Lombardy. Corsica's economic fabric is essentially made up of small and home businesses, farm smallholdings, artisans and small-scale retail. Given how public-sector capital investment is already hypertrophied, a policy of investment in human capital could be a compelling new opportunity to trigger a dynamic regional development impetus. Leading the way, the University Institute of Technology Corsica, Corsica University's affiliated school of applied vocational technologies, is demonstrating its ability to act as a structurally engaged facilitator of islandwide spatial planning and regional branding. As a founding pillar in pioneering the emergence of a sandwich-course training system in higher education in Corsica, in 2010 the university made its entire training curriculum fully accessible to all, through the signature of apprenticeship training or vocational qualifications agreements. After highlighting the specific features of the sandwich training policy development process in Corsica as a shaper of the Regional Vocational Development Programme, this paper brings an analysis of the lessons learned from the pioneering example of the University Institute of Technology Corsica as a dynamic engineer of structured future and regional brand for Corsica.
\end{abstract}

Keywords: sandwich training, employability index, school-to-work transition, regional branding,

Cite this Article as: Christophe Storaï and Laetitia Rinieri (2014)," Sandwich Training in Higher Education as one Major Strategic Axis at the Heart of the Attractiveness of a Territory: Some Lessons Learned from the Pioneering Example of the University Institute of Technology Corsica", Journal of e-Learning and Higher Education, Vol. 2014 (2014), Article ID 292497, DOI: 10.5171/2014.292497 


\section{Introduction}

A new and much-hyped concept in the economics literature has now emerged into a major strategic thrust for regions in fierce global competition to capture and secure geographically-mobile investment: attractiveness, or regional branding. In this environment, the challenge of cohabiting a two-pronged policy of sustainable development and regional branding requires coordination across several fronts, where early-stage tech entrepreneurship,, and human capital feature high on the list of critical variables.

Regional branding is the new paradigm to create jobs, boost inward investment into industry and services, unlock the international marketplace and gain access to new technologies. Winning potential investors is therefore,, a major objective for any regional territory, regardless of its development stage (Michalet, 1999). Territorial attractiveness hinges on a series of location-related assets that are made capital by the fact that firms will only locate to sites that can bring competitive advantage. Businesses are receptive to a specific destination-branded offering that maps out the locational advantage, and on the lookout for specialist skills and local know-how. The attractiveness criteria for a regional brand go way beyond differences in 'natural' factor endowment.

Here, public services policy plays a pivotal role in leveraging success factors for place branding, notably through education and vocational training, and through R\&D backing. Regional-entrepreneurial dynamics can only be progressively engineered. The process starts by improving the quality of the business environment, after which the second step is to meet the needs expressed by potential investors. This is where educational training strategies are a particularly key factor for spurring the availability of skilled qualified human resources,, and unlocking innovative highpotential entrepreneurship (Marchesnay et al, 2006). Extending on this idea, entrepreneurial ecosystems built on the competitiveness clusters model founded on core tech research, and engineered with SMEs enrolled in the governance framework,, offer a potential source of sustainable regional-level structural planning and development (Veltz, 1997; Colletis \& Pecqueur, 1996). The process ultimately impels the existence of a competitive web of local enterprise. The relationship between Stanford University and Silicon Valley offers a telling example of the positive externalities of a cooperative tech research/training strategy match-up.

Corsica is an island economy marked by the complete absence of any of the big multinationals that fuel and forge the worldwide economy. Equally absent are any of the kind of medium-sized enterprises servicing big business that have spearheaded local economies in other regions like Lombardy. Corsica's economic fabric is essentially made up of small and home businesses, farm smallholdings, artisans and small-scale retail. Given how public-sector capital investment is already hypertrophied, the private sector looks like the only viable option capable of triggering a dynamic regional development impetus. It would necessarily entailss coordinately forging a duel strategy of training up human resources, and engaging a technology research process aimed at increasing the needed island-wide competency levels to national and international competency standards frameworks.

Leading the way, the University Institute of Technology Corsica, Corsica University's affiliated school of applied vocational technologies, is demonstrating its ability to act as a structurally engaged facilitator of island-wide spatial planning and regional branding. As a founding pillar in pioneering the emergence of a sandwich-course training system in higher education in Corsica, in 2010 the university made its entire training curriculum fully accessible to all through the signature of apprenticeship training or vocational qualifications agreements. This 
grass-roots programme is the outcome of a committed core strategy to develop partnerships with the island's key social and economic communities (businesses, community groups and local authorities), and it plays a fundamental role in shaping,, and selling the most vital valued assets that typify a regional territory,, emerging into a structured destination-brand identity (simultaneous growth in the employability and quality of school-to-work transition shown by its human capital, mass shift in the degree of skill acquisition directly tied to the regional territory's own organic needs, fluidity of knowledge transfer fully controlled through sandwich placements, deep sustainable entrepreneurship education, and so on).

It is precisely, this University Institute of Technology Corsica sandwich-student school-to-work transition issue, reframed as pivotal to local regional development strategy, that this paper aims to highlight as a real-world example of how to deal with specific constraints facing a small-island economy.

\section{University Institute of Technology Corsica, Pioneering the Development of a Sandwich-Course Training System in Higher Education in the Corsica Region}

The IUT of Corsica faculty created the very first apprenticeship 'section' in Corsicaregion higher education, back in the 2001/2002 academic year. Originally, targeting just one professionally-oriented undergraduate course (the University Technical Diploma ['DUT'] in Business and Administrative Management) enrolling 12 students, the initiative hived off into every single course curriculum on offer. ${ }^{i}$ The dynamic momentum engaged by this bridge to the business world sparked the creation of Corsica-region University Placements \& Careers Service [CFA UNIV] tasked with handling the promotion, development, and administrative-educative-financial management of the sandwich-course system at the University of Corsica.
At the start of the 2012/2013 academic year (September 2012), the University Institute of Technology Corsica counted 150 sandwichplacement students (i.e. $25 \%$ of student enrolment at the faculty) ${ }^{\mathrm{ii}}$ representing $54.4 \%$ of students going through the University of Corsica-led sandwichplacement scheme, and $30 \%$ of sandwichplacement students in Corsica-region higher education as a whole.

Sandwich-placement Training in Higher Education as a Shaper of the Regional Vocational Development Programme

Corsica offers a case-in-point example of an areal region characterized by an ageing labor force, making it necessary to re-align midterm regional vocational training strategy in response to this inescapable reality. As a major lever of local-regional development and social regulation policy, the island's vocational training system has to re-adapt its offer to achieve the targeted job-to-training fit. Continuing professional education, and the sandwich-course system (apprenticeships, sandwich-course internships) are therefore, the two core strands of the same policy platform designed to structure and build the competency levels, qualifications and employability of the employed and unemployed labor force a given territory.

With commentators touting the knowledge economy as the only way out from endemic economic crisis, the University Institute of Technology Corsica has taken a pro-active role by engaging in a process to structure a consolidated, sustainable socio-economic fabric though optimized management of its vocational training/information, guidance services and tailored careers support system. The faculty, thus works in close collaboration with the CFA UNIV, which leaders the annual survey 10 specifically geared to sandwichplacement students (monitoring school-towork transition figures for sandwich-course leavers (graduated or not) in March the following year). 


\section{Ministry-Sponsored Surveys on the Transition-to-Work of University Institute of Technology Corsica Graduates}

For this purpose, a specific survey targeted at measuring school-to-work transition by University Institute of Technology Corsica, students were adopted as a performance instrument, but also to provide statistical support to predictive policy building on directions; that future vocational training efforts should take in order to fill human resources gaps in the Corsican socioeconomic fabric. This predictive strand is a crucial factor, as the analyses produced are designed to guide the political (CTC) ${ }^{\mathrm{iii}}$ and institutional (the University) decisionmakers in their coordinated effort to roadmap a vocational strand of Corsicaregion higher education geared to localspecific factors and variables.

The analyses developed are built around nine core focuses:

- The professional status of the sandwich-placement student

- Job level (occupational category)

- The time gap before integrating the current position

- The contract type (long-term, shortterm...)

- The in-job salary of the sandwichplacement student

- The job-to-training fit (whether the job position is an extension of curriculum completed)

- Geographic location of the job found

- Structure taking on the sandwichcourse leaver (businesses, community groups, local authorities)

- Link to the initial sandwichplacement structure

Moving from Expected Outcomes to Predictive Values Ready to Devise a Structured Sustainable Areal Development Roadmap

Stemming from the University of Corsica's ministerial accountabilities (nationally- coordinated regional-scale survey led by universities offering a broad-spectrum vocational development curriculum), Corsica-region local government (CTC), simultaneously exercising its mission to promote regional apprenticeship schemes ${ }^{i v}$, and its mission to validate the map of regional-scale coverage of training programmes ${ }^{\mathrm{v}}$, commissions the University of Corsica (via the CFA UNIV) to annually provide tangible figures on graduation rates, and school-to-work transition record to inform and shape political policy decisions on the island's Regional Vocational Development Programme ('PRDF').

This tool, wielded by regional government, informs mid-term regional vocational training policy, and the aligned coordination of the vocational training paths on offer. To forge the plan, the CTC relies on active input from the Corsica's educative, economic and social community networks.

Close-up look at the school-to-work transition record of sandwich-placement students leaving the University Institute of Technology Corsica in 2011 and 2012 vi

The University Institute of Technology-Corsica vocational curriculum courses surveyed illustrates five core activity areas representative of university teaching, opened up to directly fill gaps in the islandwide socio-economic fabric.

Management: DUT [university technical diploma] in Business and Administrative Management ('DUT GEA'); LP [national professional-vocational bachelor's degree] in Entrepreneurship('LPE'); LP Banking and Finance

Commerce: DUT Marketing Techniques; LP Commerce: value creation and food-industry products

Computing and Communications: DUT Communication Networks and Services; LP Audiovisual techniques; DU [university-issue degree diploma] in Audiovisual engineering 
Industry: DUT Civil Engineering, DUT Biological Engineering (biotech and foodfarming industries), LP Food-Farming Quality Engineering, LP Civil Engineering \& Construction

Environment: DUT Biological Engineering (environmental engineering); DUT HealthSafety-Environment; LP Water and Environmental Governance; LP Energy and Climate Engineering - renewable resource management.
The set covers a total 16 courses ( 7 DUT, 8 LP and 1 DU) enrolling 190 students. $^{\text {vii }}$

\section{Report and Analysis of the Main Findings}

a) Breakdown distribution of sandwichplacement students in the 5 core activity areas representative

of university teaching opened up to directly fill gaps in the island-wide socio-economic fabric

Sandwich-course leavers in 2011

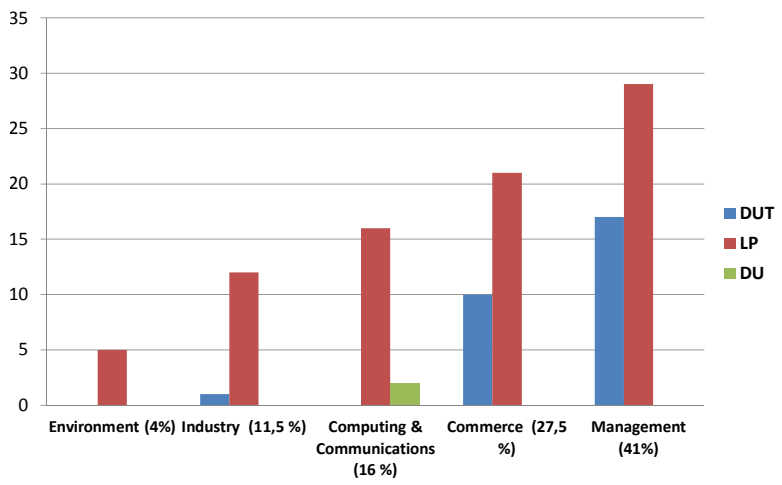

Sandwich-course leavers in 2012

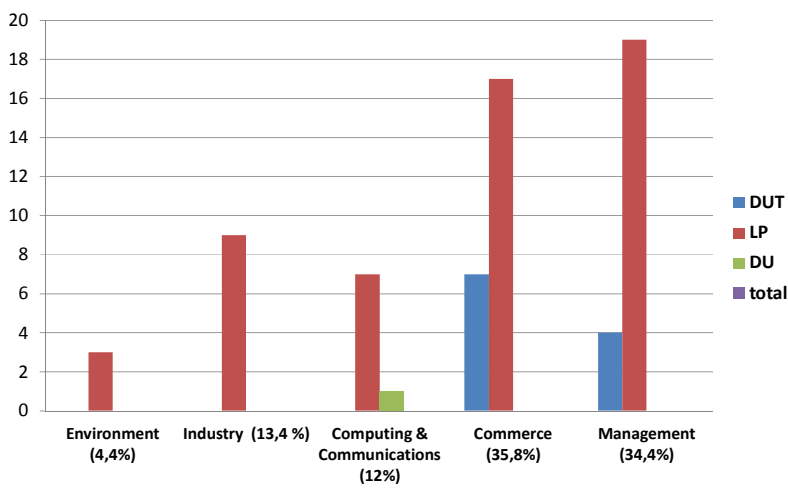

Figure 1: distribution of sandwich-course leavers 
b) Career situation of sandwich-course leavers

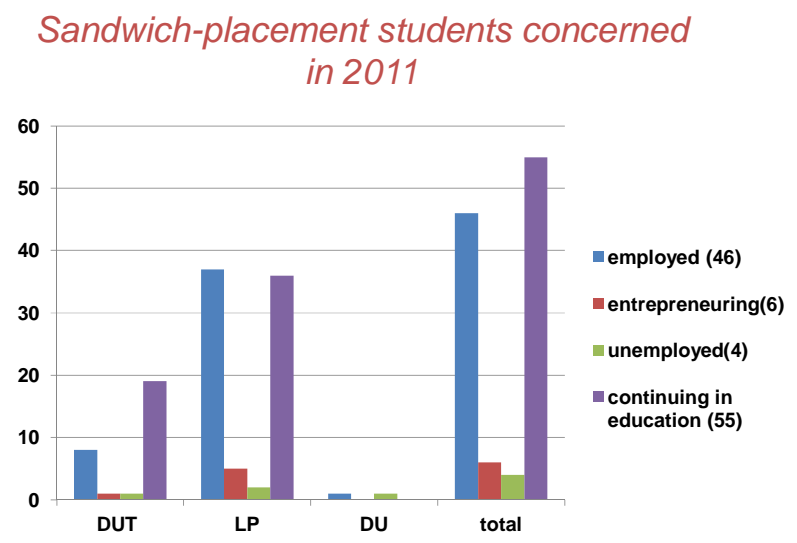

\section{Sandwich-placement students concerned} in 2012

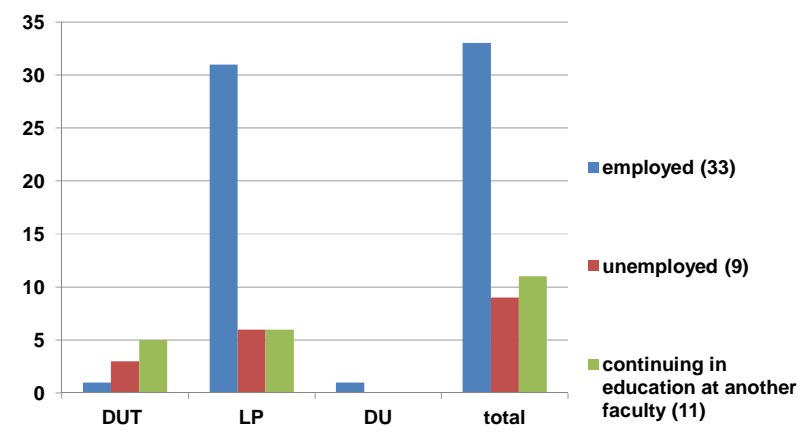

Figure 2: career situation of sandwich-course leavers 
c) Types of job contracts held by sandwich-course leavers

Contract type for the 54 sandwich-

placement students concerned in 2011

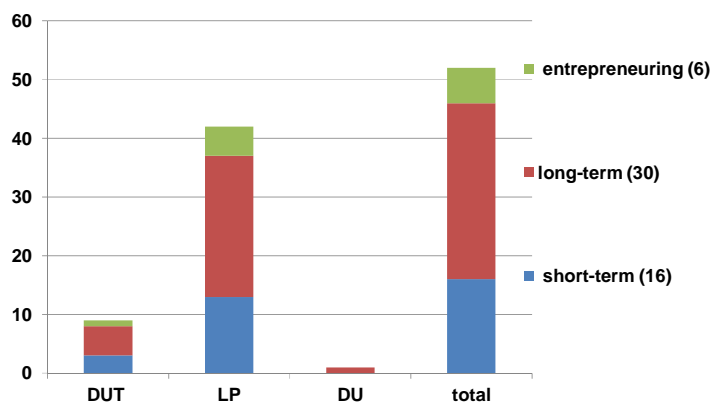

Contract type for the 33 sandwichplacement students concerned in 2012

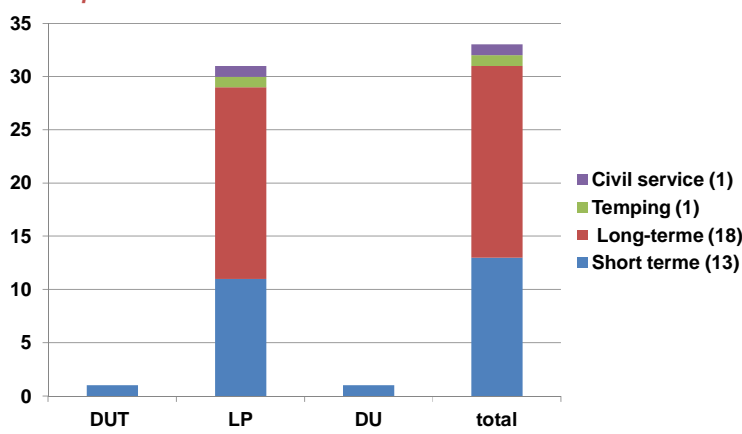

Figure 3: types of job contracts held by sandwich-course leavers 
d) Types of occupational categories held by sandwich-course leavers

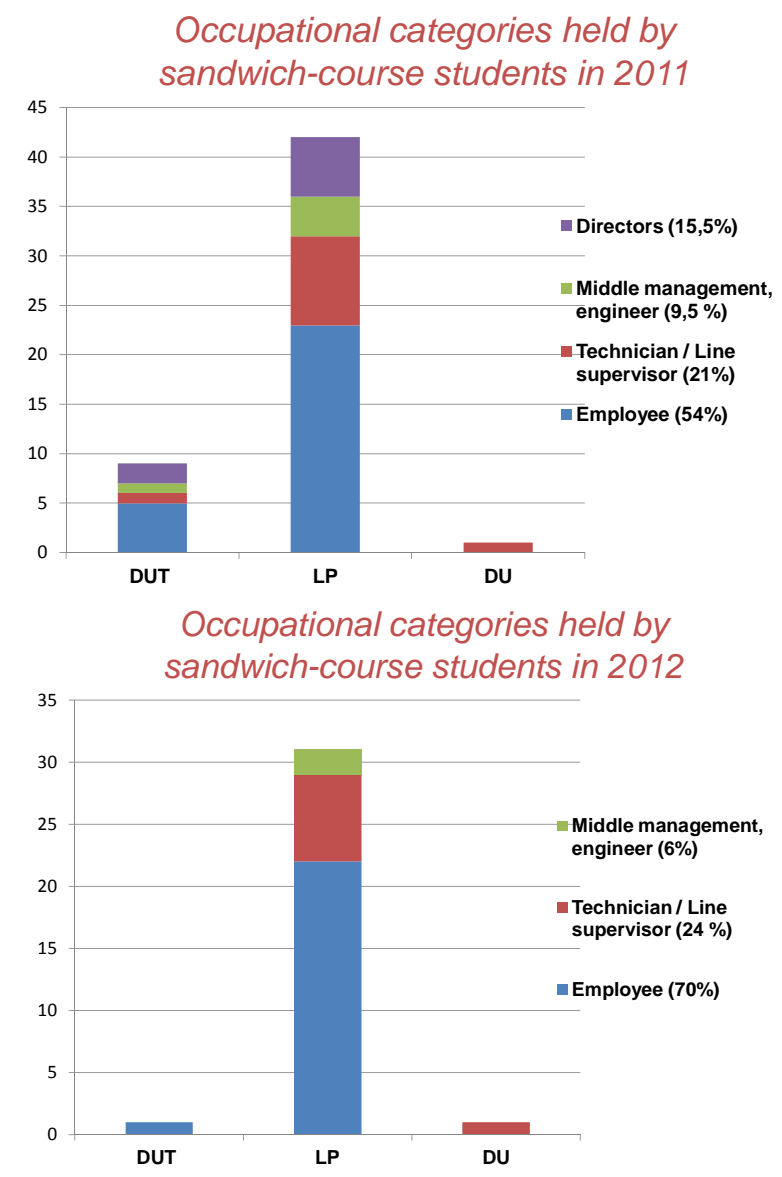

Figure 4: types of occupational categories held by sandwich-course leavers 
e) Job-to-training fit for sandwich-course leavers

\section{Sandwich-course students on placement \\ in their trained-for sector in 2011 \\ $90.3 \%$ sandwich-placement students(i.e 47 out of 52 on} placement) hold a job that fits with their training path.

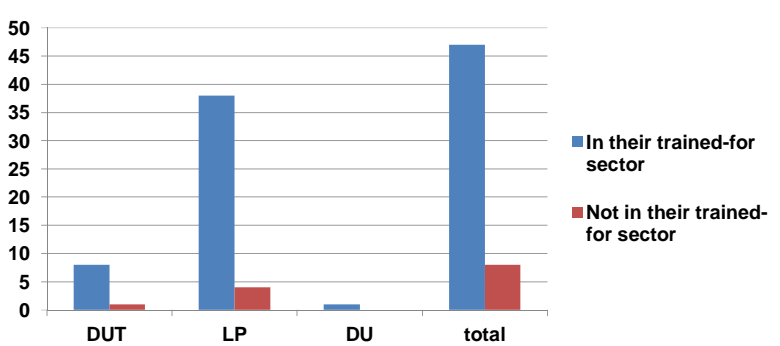

Sandwich-course students on placement

in their trained-for sector in 2012

$81,8 \%$ sandwich-placement students(33 hold a job that fits with their training path).

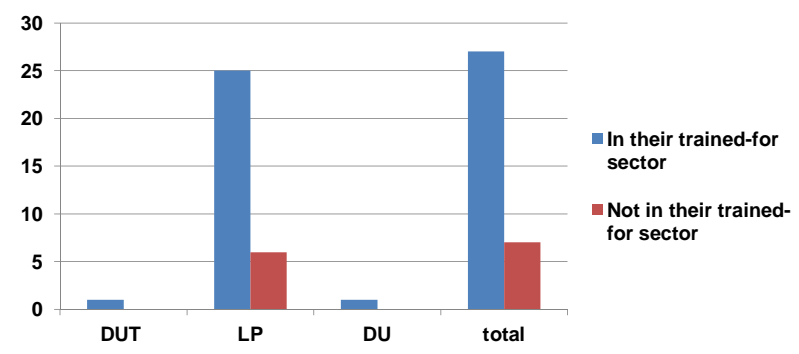

Figure 5: job-to-training fit for sandwich-course leavers 
f) Sector structures taking on sandwich-course leavers

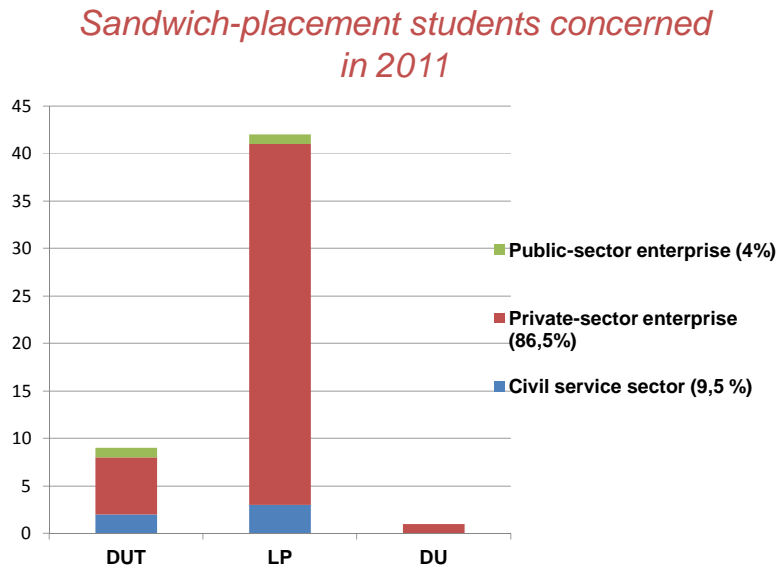

Sandwich-placement students concerned in 2012

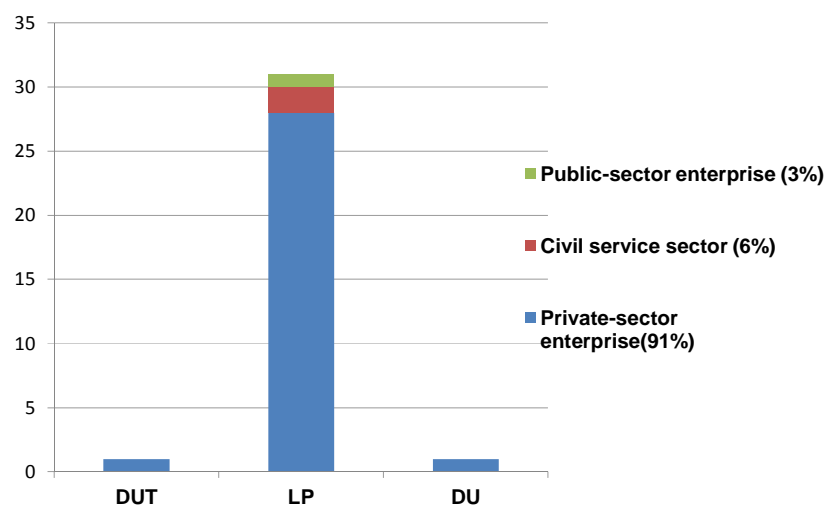

Figure 6: sector structures taking on sandwich-course leavers 
g) Size of structures taking on sandwich-course leavers

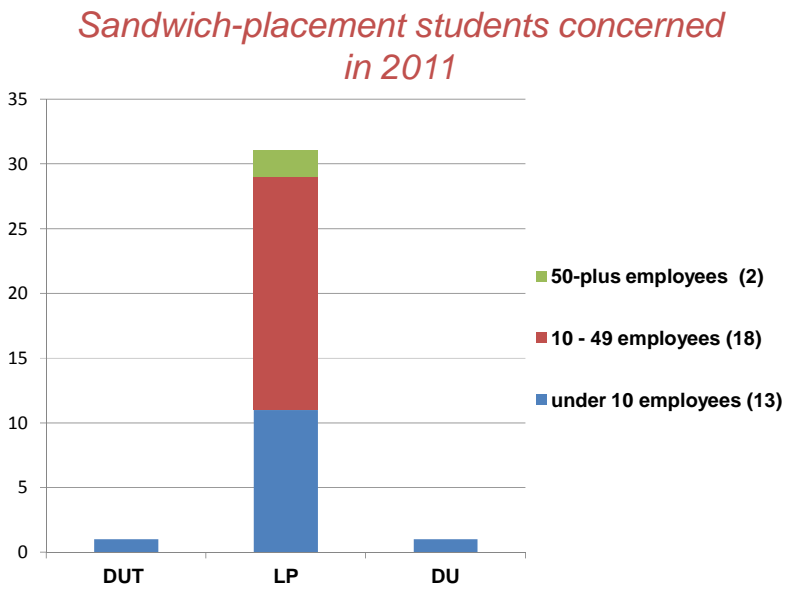

Sandwich-placement students concerned

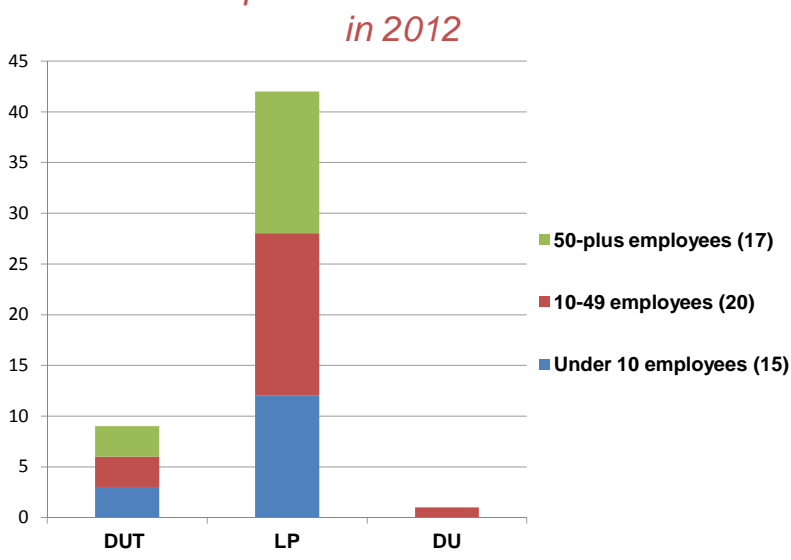

Figure 7: Size of Structures Taking On Sandwich-Course Leavers 
h) Geographic location of jobs found by sandwich-course leavers

Sandwich-placement students concerned in 2011

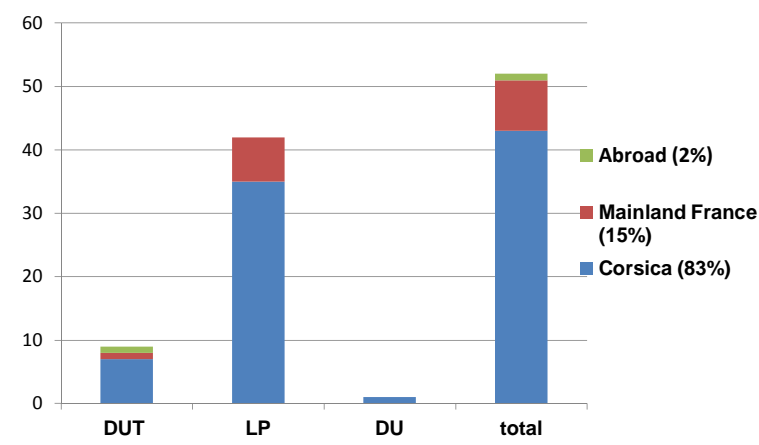

Sandwich-placement students concerned in 2012

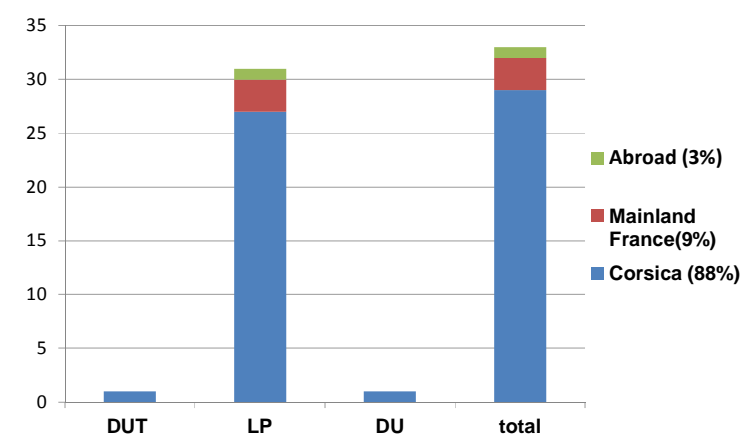

Figure 8: Geographic Location of Jobs Found By Sandwich-Course Leavers 
i) Salary brackets of job contracts held by sandwich-course leavers

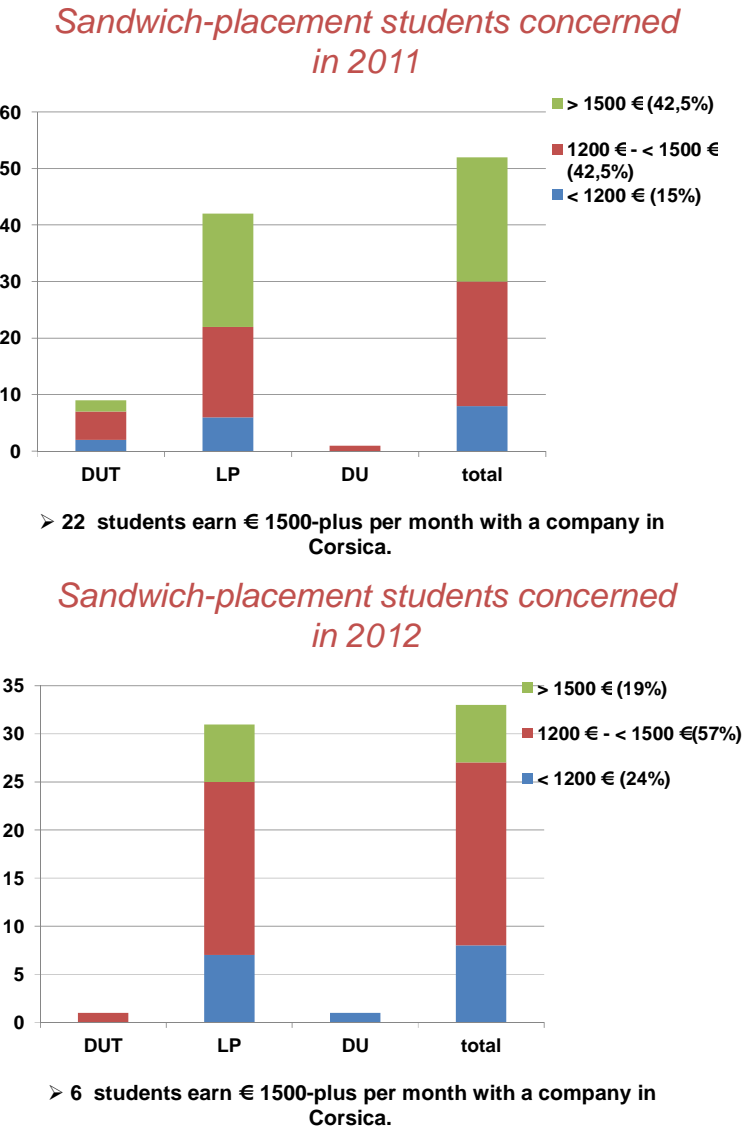

Figure 9: Salary Brackets of Job Contracts Held By Sandwich-Course Leavers

i) Examples of the kinds of jobs held by sandwich-course leavers

- Sales representative;

- Accountant;

- Research officer;

- Project site supervisor;

- Laboratory technician;

- Construction superintendent;

- Network leakage technician;

- PR assistant;

- Customer support assistant;

- Risk prevention engineer... 
k) Situation of sandwich-course leavers continuing in education at another faculty

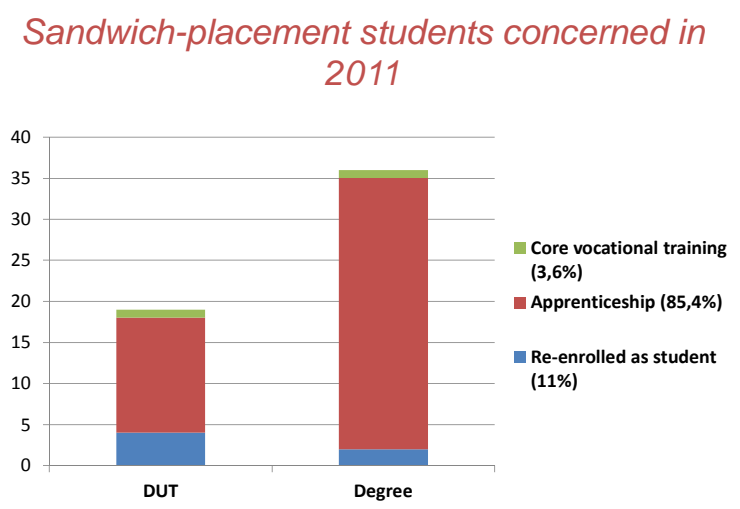

\section{Sandwich-placement students concerned in 2012}

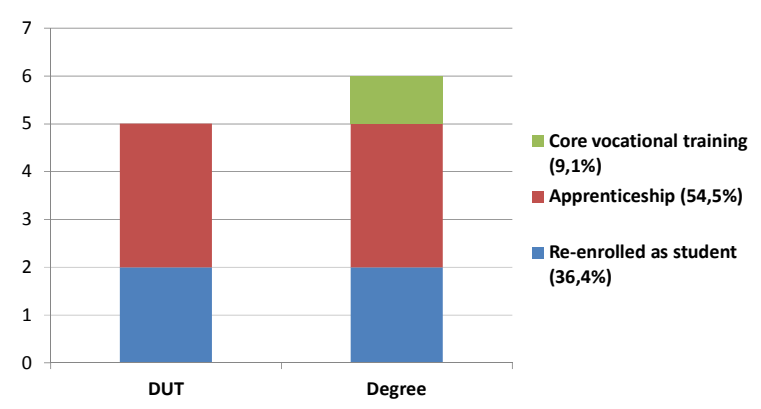

Figure 10: Situation of Sandwich-Course Leavers Continuing In Education 
h) Reasons pushing sandwich-course leavers to continue education at another faculty

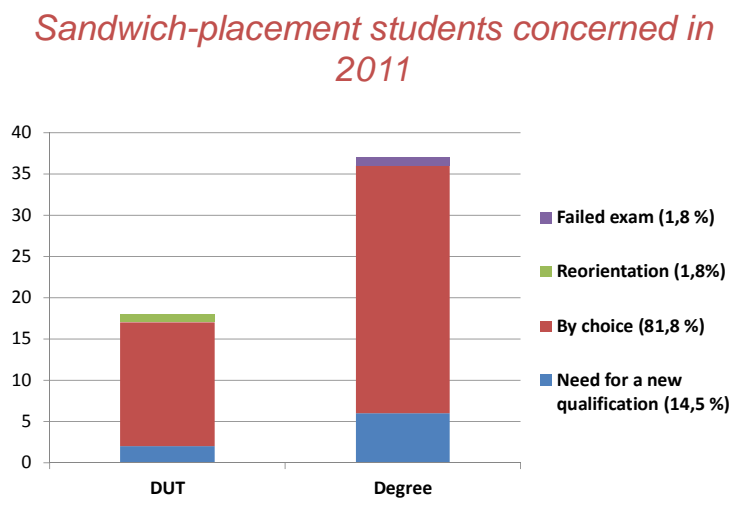

\section{Sandwich-placement students concerned in 2012}

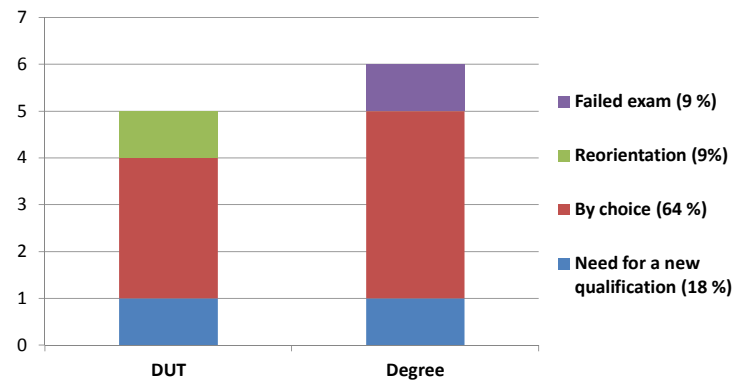

Figure 11: Reasons Pushing Sandwich-Course Leavers To Continue In Education

\section{Conclusion}

The survey findings point to particularly encouraging signs on employability and quality of school-to-work transition of University Institute of Technology-Corsica students, especially in the analysis of targeted job-to-training fit. This grass-roots reality opens up promising future perspectives for a structured entrepreneurial fabric in Corsica built on the sandwichcourse system platform, where placement businesses are centrally empowered to train up young local talent.
Ultimately, the overriding objective remains to successfully coordinate the impetus given to vocational training as a solution to fill gaps in the island-wide socio-economic fabric (maximization of the job-to-education fit) through the emergence of sandwich-course training channels (tiers III, II and I). Moving towards this objective, the findings of the joint-led University Institute of Technology-Corsica/CFA UNIV surveys provide regional public policymakers with positive concrete guidance.

From this perspective, the joint expertise of the University Institute of Technology-Corsica, and the CFA UNIV 
brings insights that are liable to guide strategic decisions on vocational training policy, employment policy, and how to structurally shape the island as a social and economic area. These findings will be presented as part of a wider initiative to build a policy decision support tool focused on the theme of areal planning, and regional branding for Corsica.

\section{References}

1. Association of the IUT's Managers (ADIUT), (2013), "In-service training et sandwich training: the commitment of IUT in the effort of economic and industrial energization of regions", Colloquium FCA, IUT of Tarbes, 29-31 May.

2. Ceccarini A. and Storaï C. (2011), "The sandwich training in Higher Education: an excellent way and a foodbridge towards the employment, the teachings of the University Vocational Training Center (CFA UNIV) in région Corsica", XVIème colloquium CNR IUT, Cherbourg-Octeville, 8-10 June 2011.

3. Colletis G. and Pecqueur B. (1996), "Firms and territories: between nomadism and anchoring", Revue Espaces et Sociétés $n^{\circ}$ spécial.

4. Dares, (2012), The national spending for the in-service training and the apprenticeship trainiing in region, January.

5. Furt J.M. and Storaï C., (2011), "Which social organization for a patrimonial economy?" In Vivre du Patrimoine, A.Fazi \& J.M. Furt (eds), Edition l'Harmattan, pp.401409.

6. Graziani S. and Storaï C., (2009), " The sandwich training in Higher Education or how to strengthen the capacity of insertion of the young graduates? The case of the IUT of Corsica", XVème Colloquium CNR IUT, Villeneuve d'Ascq, 8-10 June.
7. Marchenay M., Kammoun S.C. and Karray H.E., (2006), " Is there a Mediterranean Entrepreneurship?" Revue Française de Gestion, Vol. 32., No. 166.

8. Michalet C.A., (1999), The Seduction of Nations or how to attract the investments, Economica, Paris.

9. Veltz P., (1996), Globalization, cities and territories. The economy of archipelago, Paris PUF.

i As of September 2010, the entire University Institute of Technology Corsica curriculum (6 DUTs and 9 licences professionnelles [national professionalvocational bachelor's degrees]) is on offer under sandwich placement agreements.

ii A figure that puts the IUT de Corse top of the national league table in terms of sandwich-tocampus ratio (ADIUT, 2013).

iii Collectivité Territoriale de Corse : Corsica-region local government

iv The CTC is also the system's leading sourcing of funding via the Contrat d'Objectifs et de Moyens [service objectives and infrastructure spending agreement] signed between French central government and the French regional divisions.

From primary school education through to postsecondary higher education - a central governmentsponsored mission that was devolved to the CTC via French decentralization policy on Corsica under the law dated 22 January 2002 (see French government decree 2002-92 dated 22 January 2002 concerning Corsica).

vi The raw data and the findings reported here are taken from annual survey 10 conducted by the CFA UNIV.

vii Exact figures put the survey response rates from the sandwich-placement students concerned at $91.8 \%$ in 2011 (113 respondents out of 123 surveyed) and $79.1 \%$ in 2012 (53 respondents out of 67 surveyed). 